This is the peer reviewed version of the following article: Holden J, Moody CS, Edward Turner $\mathrm{T}$, et al. Water-level dynamics in natural and artificial pools in blanket peatlands. Hydrological Processes. 2018;32:550-561, which has been published in final form at https://doi.org/10.1002/hyp.11438. This article may be used for non-commercial purposes in accordance with Wiley Terms and Conditions for self-archiving. 


\section{Water-level dynamics in natural and artificial pools in blanket peatlands}

${ }^{1}$ Holden, J., ${ }^{1}$ Moody, C., ${ }^{1,2}$ Turner, T.E. ${ }^{3,4}$ McKenzie, R., ${ }^{1}$ Baird, A.J., ${ }^{5}$ Billett, M.F., ${ }^{1}$ Chapman, P.J., ${ }^{6}$ Dinsmore, K.J., ${ }^{1}$ Grayson, R.P, ${ }^{3}$ Andersen, R., ${ }^{1}$ Gee, C., ${ }^{1}$ Dooling, G.

${ }^{1}$ water@leeds, School of Geography, University of Leeds, Leeds, LS2 9JT,

${ }^{2}$ Forestry Commission Scotland, Creebridge, Newton Stewart, Dumfries \& Galloway, DG8 6AJ

${ }^{3}$ Environmental Research Institute, North Highland College, University of the Highlands and Islands, Castle Street, Thurso, Caithness, KW14 7JD, UK,

${ }^{4}$ Department of Geography, Loughborough University, Loughborough, Leicestershire LE11 3TU, UK,

${ }^{5}$ Biological \& Environmental Sciences, Faculty of Natural Sciences, University of Stirling, Stirling, FK9 4LA,

${ }^{6}$ Centre for Ecology and Hydrology Edinburgh, Bush Estate, Penicuik, Midlothian, EH26 0QB, UK,

Corresponding author: Professor Joseph Holden, water@ leeds, School of Geography, University of Leeds, Leeds, LS2 9JT, UK j.holden@leeds.ac.uk +441133433317

Paper submitted to Hydrological Processes: 30 November 2017

\section{Abstract}

Perennial pools are common natural features of peatlands and their hydrological functioning and turnover may be important for carbon fluxes, aquatic ecology and downstream water quality.

Peatland restoration methods such as ditch blocking result in many new pools. However, little is known about the hydrological function of either pool type. We monitored six natural and six artificial pools on a Scottish blanket peatland. Pool water levels were more variable in all seasons in artificial pools having greater water level increases and faster recession responses to storms than natural pools. Pools overflowed by a median of 9 and 54 times pool volume per year for natural and artificial pools respectively but this varied widely because some large pools had small upslope catchments and vice versa. Mean peat water-table depths were similar between natural and artificial pool sites but much more variable over time at the artificial pool site, possibly due to a lower bulk specific yield across this site. Pool levels and pool-level fluctuations were not the same as those of 
42 local water tables in the adjacent peat. Pool level time-series were much smoother, with more

43 damped rainfall or recession responses than those for peat water tables. There were strong hydraulic

44 gradients between the peat and pools, with absolute water tables often being $20-30 \mathrm{~cm}$ higher or

45 lower than water levels in pools only 1-4 m away. However, as peat hydraulic conductivity was

46 very low (median of $1.5 \times 10^{-5}$ and $1.4 \times 10^{-6} \mathrm{~cm} \mathrm{~s}^{-1}$ at 30 and $50 \mathrm{~cm}$ depths at the natural pool site)

47 there was little deep subsurface flow interaction. We conclude that: 1) for peat restoration projects,

48 a larger total pool surface area is likely to result in smaller flood peaks downstream, at least during

49 summer months, because peatland bulk specific yield will be greater; and 2) surface and near-

50 surface connectivity during storm events and topographic context, rather than pool size alone, must

51 be taken into account in future peatland pool and stream chemistry studies.

52

53 Keywords: peatland, pools, water level, restoration, wetland, ponds 


\section{Introduction}

Peatlands are important carbon stores (Yu, 2012) covering around 423 million hectares of the land surface (Xu et al., 2018). Their expanse increased during the Holocene, particularly in the northern high latitudes after deglaciation, where a cool, wet climate is co-located with low-lying basins and other areas of poor drainage (Yu et al., 2010). Even on upland terrain with slopes as great as $15^{\circ}$, blanket peatlands have developed in many temperate hyperoceanic regions including parts of Atlantic northwest Europe, eastern and western Canada, southern Alaska, Tasmania, the South Island of New Zealand, the southern tip of South America and eastern Russia (Gallego-Sala and Prentice, 2012).

Peatlands are characterised by shallow water tables and are capable of storing very large volumes of water since peat soils often have porosities > $95 \%$ (Ingram, 1983; Hobbs, 1986). In addition to the peat volumetric water store, peatlands often contain open-water pools (Glaser, 1998). Multiple hypotheses have been proposed for natural pool formation and expansion in peatlands (cf. Belyea and Lancaster, 2002), but surprisingly little is known about the hydrological functioning of peatland pools. In some northern peatlands the surface area of pools can be as much as $90 \%$ of the total peatland area (e.g. Sjors, 1983) but pools more typically represent 5-30\% of the land area where they are present (e.g. Foster and Glaser, 1985; Roulet et al., 1994). Peatland pools are important for aquatic biodiversity, particularly when there is a wide variety of pool sizes (Downie et al., 1998; Beadle et al., 2015). They are also often 'hotspots' of carbon dioxide and methane emissions (Hamilton et al., 1994; Waddington and Roulet, 1996; Pelletier et al., 2014) and as such they are likely to process dissolved and particulate organic carbon altering dissolved and particulate carbon concentrations and characteristics in pools (Pickard, 2016; Turner et al., 2016), potentially influencing downstream water chemistry. Their hydrological functioning is likely to control how pools process carbon, yet little is known about hydrological processes associated with pools in peatlands. During rainfall pools may spill over, delivering water to other parts of the peatland or to 
nearby stream networks (Quinton and Roulet, 1998). Rates of pool water turnover have not been reported but could affect overall water residence times in peatlands, which in turn may be important in controlling peat decomposition rates (Beer and Blodau, 2007; Morris and Waddington, 2011) or streamwater chemistry. However, these functions have not previously been tested for natural pool systems in blanket peatlands.

Two previous short-term studies of pool hydrological function in fens and raised bogs in Canada have shown that pools can provide significant depression storage for rainfall thereby greatly reducing runoff from the system (Price and Maloney, 1994; Quinton and Roulet, 1998). Quinton and Roulet (1998) studied a narrow, valley bottom pool-patterned fen for four months and found it was dominated by two distinct phases of operation: (1) an overflow phase during spring melt and one large summer storm when water supply exceeded the depression storage capacity and the pools effectively coalesced producing diffuse surface runoff, and (2) a summer phase, without spill over, when pools were disconnected, with slow rates of groundwater inputs which were around an order of magnitude less than pool evaporation rates. A six-week study of a small fen and raised bog in Labrador indicated that the catchment runoff ratio was $<0.15$ with the pools enhancing evaporative losses (Price and Maloney, 1994). For the systems studied, Price and Maloney (1994) noted that pool position relative to the local topography and the location of peat pipes connected to pools were both important for controlling pool inflows and outflows, although pipe flows, pool outflow rates and pool levels were not directly measured. There have been no detailed studies of pool hydrological function in blanket peatlands and no natural pool hydrological function studies for any type of peatland that have continued for periods of more than a few months. 
110 Many northern peatlands have been drained for peat extraction, forestry and agriculture (e.g. Höper

111 et al., 2008). For example, drainage ditch construction was common practice between the 1940s and 112 1980s in the UK, where blanket peat covers around $7 \%$ of the land surface (Baird et al., 2009). 113 Such drainage did not achieve its aim of enhancing agricultural productivity (Stewart and Lance, 114 1983), but led to environmental problems including erosion (Mayfield and Pearson, 1972; Holden et 115 al., 2007) and, in some places, to enhanced losses of dissolved organic carbon into streams and 116 rivers (Mitchell, 1990; Mitchell and McDonald, 1995; Armstrong et al., 2010). In common with 117 many areas of the world (cf. Höper et al., 2008) where peatlands have been damaged by artificial 118 drainage, ditches in UK peatlands are being blocked. This restoration activity results in the creation 119 of thousands of small pools within the blocked ditches, which in sum can amount to a large area of 120 open water (Parry et al., 2014; Brown et al., 2016; Holden et al., 2017). It is not known to what 121 extent the hydrological functioning of these artificial peatland pools is similar to that of natural pools. Price et al. (2002) studied experimental artificial pools installed in a cutover plateau bog in Québec. They did not measure pool water levels but measured the water tables and soil tension in the surrounding peat on 76 days during the study compared to a control cutover treatment without pool creation, showing that water-tables were more stable following pool creation. This reduction in water-table variability has also been found on some sites with ditch-blocked pools in upland blanket peat in the British Isles (Holden et al., 2011). This is to be expected because the specific yield of a pool is 1 whereas the specific yield of peat is substantially less than one; if a significant proportion of a peatland is taken up by pools, its bulk specific yield will be higher than that of the peat itself.

131 The paucity of data on peatland pool hydrological functioning means that we lack understanding of 132 whether peatland open-water pool levels and their fluctuations are similar between artificial and 133 natural systems. There have been no detailed inter-annual studies of natural peatland pool 
hydrological function. We also lack basic understanding of whether water levels in pools and their

fluctuations in response to rainfall or evaporation simply reflect those of the water table in the surrounding peat. It may be that either: (1) pool water levels are well connected to local water-table levels and fluctuations in the surrounding peat; or (2) the two systems are partly independent of each other in terms of their hydrological functioning. Furthermore, pool water volume replacement and spill over rates have never been measured in blanket peatlands before. Here we report on a study in which we compared the hydrological functioning of natural and artificial blanket peatland pools. For a site in which both pool types were in close proximity, we investigated pool water-level dynamics, established rates of pool water replenishment (turnover), and examined water-table fluctuations in the peat surrounding the pools.

\section{Methods}

Six natural pools (Pools 1-6) and six artificial pools (Pools 7-12) were chosen for investigation (Figure 1) at Cross Lochs peatland in the Flow Country, northern Scotland (58 $22^{\prime}$ N, $03^{\circ} 57^{\prime} \mathrm{W}$ ), at 215 m altitude (Figure 1) between 2013 and 2016. The Flow Country bog system is the UK's largest single tract of peatland covering $4000 \mathrm{~km}^{2}$ (Ingram, 1987; Lindsay et al., 1988). It has many intact pool systems similar to those in a range of other blanket bog systems in Scotland (e.g. Boatman, 1983; Ratcliffe and Oswald, 1988; Belyea, 2007) and peatland pool systems in continental settings (e.g. Glaser, 1998). The climate of the area is cool with a mean annual temperature for $1981-2010$ of $7.6^{\circ} \mathrm{C}$ and a mean annual precipitation of $1196 \mathrm{~mm}$ for Altnaharra meteorological station, $\sim 30 \mathrm{~km}$ from Cross Lochs. While snowfall may occur at the site in winter, it is synoptically controlled and will often melt completely within a few days. Rainfall is much more common in winter than snow. Peat depths at the site were measured using rod probing and ranged from $0.94 \mathrm{~m}$ to $4.00 \mathrm{~m}$ which is in line with earlier surveys in the area (Ratcliffe and Payne, 2016). The underlying geology forms part of the Moine Supergroup with Pre-Cambrian migmatitic pelite and semipelite metamorphic rocks. The vegetation is dominated by mosses, sedges and small 
shrubs. Mosses mainly include Sphagnum cuspidatum, S. denticulatum, S. fallax, S. capillifolium, $S$. subnitens, S. papillosum S. tenellum and Racomitrium lanuginosum. Liverworts such as Plurozia purporea are abundant at the site. Sedges, mainly Eriophorum vaginatum and E. angustifolium and small shrubs, mainly Calluna vulgaris and Erica tetralix, are widespread.

The natural and artificial pool sites were close to each other (within c. $400-600$ m; Figure 1). The mean slope was 0.04 across the natural pool site and $0.05 \mathrm{~m} \mathrm{~m}^{-1}$ across the artificial pool site. Pools covered $8.6 \%$ of the surface area of the natural pool site and $0.7 \%$ of the artificial pool site. The northwest section of Figure 1 shows a nearby block that was subject to plantation forestry which has been felled. However, this forest restoration block is beyond the drainage divide and does not interact with the natural or artificial pool sites we studied. The selected pools were deemed to be representative of the pools across the site. Pools, particularly natural pools, often have uneven beds and so transects in two directions across each pool were surveyed to calculate pool depths; for the larger pools this resulted in around 30 depth measurements per pool whereas for small $\left(\sim<9 \mathrm{~m}^{2}\right)$ pools there were 4-10 depth measurements per pool. Natural pools ranged in size from $9 \mathrm{~m}^{2}$ to 868 $\mathrm{m}^{2}$ (Table 1) while the range of sizes for artificial pools was much smaller at $1 \mathrm{~m}^{2}$ to $6 \mathrm{~m}^{2}$. The catchment area for each pool was calculated based on surface topography and the approximate length of the perimeter that received surface water from an upslope topographic area was also determined (Table 1). For most of the natural pools more than half of their perimeter received water from upslope, whereas for all of the artificial pools less than a third of their perimeter received surface drainage water from upslope. The mean water heights above pool bed for natural and artificial pools were comparable $(38 \mathrm{~cm}$ and $39 \mathrm{~cm}$ respectively; Table 1$)$. The artificial pools were created behind peat dams constructed in 2002 , located within artificial drainage ditches that had been dug in the 1970s. The artificial pools were constructed in a typical manner for blanket peatlands in the UK (Parry et al., 2014) with peat excavated from one side of the ditch at the dam location, thereby widening the ditch at the location where the pool is formed. The excavated peat 
was used to form the dam, with the original vegetation layer from the excavated peat placed onto the dam top to help stabilise it. Only one artificial pool per ditch was chosen for study.

Meteorological data were collected on site using a Davis Vantage Pro 2 automatic weather station. Open water evaporation from the pools was calculated using the Penman (1948) open water equation which is physically based and uses temperature, relative humidity, wind speed and solar radiation data. The equation has been shown to be robust during comparison studies with other equations or directly measured rates of open water evaporation (Linacre, 1993; McMahon et al., 2016).

Wooden boarding was used at key locations to minimise the impacts of disturbance during site visits and snow shoes were used throughout the year to reduce the effects of foot traffic on the peat system. All pools were instrumented in late May 2013 with automated water-level loggers (In Situ Level TROLL 500, accuracy $\pm 3 \mathrm{~mm}$ ) housed within slotted stilling wells and set to record at 15 minute intervals. Here we consider data collected between 1st July 2013 and 28th January 2016. Pool water level data are either reported as water height above pool bed or as depth-below-peatsurface' (DBPS) (distance from the peat surface on the pool edge down to the water surface in the pool). A peat-surface datum was used close to the stilling well in each pool. However, it should be noted that the topography of pool perimeters varies so that the distance from the peat surface to the pool water surface also varies along the pool perimeter. At some locations along the pool perimeter the DBPS may be several $\mathrm{cm}$, while at other points along the perimeter it may be zero and water may be spilling out from the pool. A repeated-measures ANOVA was used to test for differences in DBPS between seasons $($ winter $=$ December to February; spring $=$ March to May, summer $=$ June to August, autumn $=$ September to November) and pool type. SAS v9.4 was used for statistical analysis; all data were checked for normal distribution and a $p$ level of 0.05 was used for 
211 significance. For the repeated measures ANOVA, the data were tested using Mauchly's test for 212 sphericity, and a polynomial transformation carried out.

214 For each pool, DBPS responses to the 20 largest storm events observed over the monitoring period 215 were analysed. The DBPS values for each pool before each storm commenced, and the smallest 216 DBPS values during or immediately after each storm, were determined along with the lag time from 217 rain start to smallest DBPS. Pool level recession responses were also analysed by extracting the 218 DBPS values 6 hours and 12 hours after the smallest DBPS values were recorded and a recession 219 rate calculated in $\mathrm{cm} \mathrm{hr}^{-1}$. Two-sample $t$-tests were used to test for differences in storm response 220 variables, including recession rates, between the natural and artificial pools.

Crest-stage tubes (Burt and Gardiner, 1984), with holes placed flush with the peat surface were used to collect overland flow on the peat at the upslope end of each pool and at the downstream exit points of each pool. These tubes were checked during each site visit (47 in total between June 2013 and January 2016) and a record kept of whether they were full or empty. If they contained water they were emptied.

Ten PVC dipwells, with a $28.4 \mathrm{~mm}$ inside diameter and with $8 \mathrm{~mm}$ diameter holes drilled at $50 \mathrm{~mm}$ intervals along their length (two lines of holes along the dipwells), were installed in July 2013. A dipwell was installed in the peat $1 \mathrm{~m}$ away from each pool, but because Pools 3 and 4 were close to each other, and also Pools 5 and 6, one dipwell was located between each of these pairs (still around $2321 \mathrm{~m}$ from pool edges), giving 10 dipwells in total. Water tables were manually measured using a 233 dipmeter on each site visit until January 2016. In May 2015 an additional ten dipwells were 234 installed with six located in the natural pool system and four in the artificial pool system, each of which was instrumented with an In Situ Level TROLL 500 logger to record water tables at 15minute intervals. The instrumented dipwells at the natural site were located next to two pools, with 
a dipwell upslope, midslope (i.e., at the side of the pool) and downslope of Pool 1 (coded P1U, 238 P1M, P1D) and Pool 4 (P4U, P4M, P4D). At the artificial site the instrumented dipwells were 239 located upslope and downslope of Pools 8 and 11 (P8U, P8D, P11U, P11D). All dipwells were 240 located between 1 and $4 \mathrm{~m}$ from pool edges (1.5 to $2 \mathrm{~m}$ away in the case of the artificial pools). 241 Response time tests were carried out on the dipwells, with full recovery after slug withdrawal occurring within 15 minutes in all cases indicating that the dipwell data are reliable. A topographic survey of all dipwells and stilling wells at the two sites allowed the water-table depths to be compared between the pools and instrumented dipwells, relative to a datum at each site. Eleven large storm events occurred during the period when automated dipwell data were available. Watertable data were extracted from the automated dipwell records for these storms using the same approach as for pool levels described above, and were analysed using a one-way ANOVA with a post-hoc Tukey test.

Hydraulic conductivity $(K)$ was measured in the peat at the natural pool site using piezometer slug withdrawal tests. Piezometers were constructed from high-density polyethylene, with a $3.2 \mathrm{~cm}$ outside diameter and $2.5 \mathrm{~cm}$ inside diameter, and were installed into pre-augured holes and then 'developed' to remove any smeared peat from around the intake holes (Baird et al., 2004). The intakes were $10 \mathrm{~cm}$ long and had a pattern of perforation the same as that reported in Baird et al. (2004). $K$ was determined at 20 locations where the intakes covered depths of 45 to $55 \mathrm{~cm}$ (hereafter termed $50 \mathrm{~cm}$ depth) and 20 locations where depths of $25-35 \mathrm{~cm}$ were sampled (hereafter termed $30 \mathrm{~cm}$ depth). $K$ was calculated using the method (based on Hvorslev (1951)) reported in Baird et al. (2004) and were corrected to a temperature of $20^{\circ} \mathrm{C}$. Von Post scores for the peat at the intake depths, extracted when the piezometer holes were augered out, were determined using the descriptions given in Table 5.2 in Rydin and Jeglum (2006).

\section{Results}


DBPS values were significantly shallower for natural pools than for artificial pools $(p<0.01)$, and the repeated-measures ANOVA showed that there were significant differences between seasons $(p<0.01)$. Following a dry first summer (2013) after instrument installation (111 mm rainfall; Table 2), DBPS values in the 12 pools were greater throughout the subsequent winter than they were in the next two winters, showing inter-annual variability in pool levels even for winter months (Figure 2). The larger DBPS values- (i.e. lower water levels in pools) in winter $2013 / 14$ compared to the other winters also stand out because 2013/14 was by far the wettest of the three winters studied (Table 2). The largest variability in DBPS occurred during summer. Except for autumn 2013, DBPS values in the artificial pools in all seasons and all years were more variable than those in the natural pools (Table 2).

Irrespective of pool type, evaporation losses were equivalent to around $42 \%$ of direct rainfall inputs to the pools across the whole study. During summer, evaporative losses from pools exceeded direct input rainfall, whereas for the remaining seasons evaporative losses were lower than direct rainfall received by the pools (Table 2). However, the depth of evaporative loss was larger in two of the summers than the mean difference between winter and summer pool levels for both natural and artificial pools showing that pools must receive some inflow water from overland flow or from the surrounding peat. The net surplus of water at other times of the year means that pools must overflow and send water downslope. Considering the topographic contributing area for each pool and evaporation losses, the net outflow from pools across or through the peat downslope equated to a median of 9 and 54 times pool volume per year for the natural and artificial pools respectively

(Table 3). However, there was a wide variability in the number of times per year the equivalent pool water volume was replaced between pools ( 2 to 402 for natural pools and 19 to 714 for the artificial pools), largely driven by the fact that some large pools (e.g. Pool 1) had a small upslope contributing area compared to the pool area (Table 1). Holden et al. (2017) showed that the 
surface area alone. Therefore, the subsurface catchment area for the pools may not exactly match their surface catchment area and our values of pool catchment area should be considered estimates.

294 Overland flow was a common occurrence across the site. On average (median) the upslope creststage tubes had captured overland flow between visits 83 and $84 \%$ of the time for the natural and artificial pools respectively, while for the downslope sites overland flow occurred between 77 and $83 \%$ of visits for the natural and artificial pools respectively.

There was a significant difference $(p=0.01)$ in the changes in water height above pool bed during storm events between the two types of pools; the artificial pools had a significantly greater water level change in response to rain (mean change $3.6 \mathrm{~cm}$ ) than the natural pools (mean change $1.9 \mathrm{~cm}$ ). A regression analysis showed the relationship between cumulative rain in an event and the change in pool water height above bed was: [Natural pool surface level change $(\mathrm{cm})=0.016 \times \mathrm{mm}$ of rain +1.420 ] and [Artificial pool water level change $(\mathrm{cm})=0.016 \times \mathrm{mm}$ of rain +2.894 ], both having the same gradients. There was a significant difference between the mean response time for pools to reach peak level between the two treatments $(p=0.03$; natural mean $=17.6 \mathrm{hrs}$, artificial mean $=$ $14.6 \mathrm{hrs})$. Pool water heights above bed fell significantly $(p<0.01)$ more quickly in the 6 and 12 hour periods after rainfall in the artificial pools compared to the natural pools (Table 4). The mean recession rate was greater for every artificial pool compared to any of the natural pools. Tests of correlation between annual pool outflow or turnover frequency (Table 3) and all of the storm response variables shown in Table 4 were conducted but only two combinations of variables were significantly correlated: annual pool outflow and smallest DBPS during storm (natural pools, $r=0.80, p=0.03$ ); annual pool outflow and 6-hr recession rate (artificial pools, $r=0.74, p=0.04)$. 
system. However, water-table depths tended to have a greater range in the peat around the artificial

318 pools than in the peat around the natural pools (Figure 3).

The automated water-table records are only available from May 2015 to January 2016. During this period the average water-table depth (relative to the peat surface) at the natural site was $5.0 \mathrm{~cm}$, compared with $4.0 \mathrm{~cm}$ at the artificial site, although this (apparent) difference was not significant. $(p=0.28)$. As with the manual dipwell measurements, the standard deviations of the water-table depth were generally larger in the peat around the artificial pools than in the peat around the natural pools (Table 5). Using water-table responses to individual rainfall events (rise to rain ratios (e.g. Bourgault et al., 2017)) we estimated the mean specific yield for the upper $20 \mathrm{~cm}$ of peat to be 0.24 $($ standard error $=0.04)$ and $0.25($ standard error $=0.03)$ for the natural and artificial pool sites respectively. The storm event data showed that the relationship between water-table depth $(\mathrm{cm})$ and the ratio of water-table rise to rainfall (unitless) was linear, increasing over depth with a gradient of 0.57 . This is equivalent to a non-linear gradient of decline in specific yield with peat depth of: [1.75 /(water-table depth, $\mathrm{cm})]$. As the storm events studied did not cover periods of very deep water tables, we used the above relationship to extend estimates of specific yield to a peat depth of $40 \mathrm{~cm}$, equivalent to the mean depth of the pools. This resulted in a mean specific yield of 0.22 for the upper $40 \mathrm{~cm}$ of peat.

When comparing pool levels and peat water-table heights for the period when automated records were available for both, the range of water levels was smallest in the natural pools (mean range $=$ $7.6 \mathrm{~cm}$ ) and largest in peat water tables at the artificial pool site (mean range $=19.3 \mathrm{~cm}$ ). The range 339 in water level was significantly different between the pools and peat dipwells at both the natural and artificial sites (one-way ANOVA on mean range water level, $p<0.01$ ).Post-hoc Tukey tests showed

341 the range was significantly lower in the natural pools than for artificial pools or peat water tables.

342 There was no significant difference in range between water levels recorded in natural pool site 
343 dipwells and artificial pools, but a significantly higher range in the artificial pool site dipwells than 344 pool levels at either site or than in the natural pool site dipwells. The mean relative water level for 345 Pool 1 and the three nearest peat dipwells showed the downslope dipwell (P1D) had a lower 346 absolute water-table height, the mid-slope dipwell (P1M) had a similar mean water-table height to 347 the pool level and the upslope dipwell (P1U) had a higher mean water table (Figure 4). The mean 348 difference in relative water height between Pool 1 and the water table in the peat was -7.1, 0.5 and $34910.9 \mathrm{~cm}$ (P1U, P1M and P1D respectively). For Pool 4 the peat water tables were very different 350 from pool water level (differences of $-5.9,22.5$ and $30.3 \mathrm{~cm}$ for P4U, P4M and P4D respectively). 351 At the artificial pool site, Pool 8 mean water level was $23.3 \mathrm{~cm}$ lower than mean water-table height 352 at P8U and $11.0 \mathrm{~cm}$ higher than at P8D while Pool 11 mean level was $24.0 \mathrm{~cm}$ lower than water353 table height at P11U and $9.0 \mathrm{~cm}$ higher than at P11D.

355 The automated water-table records followed a similar seasonal pattern to the pools; the deepest mean water-tables were in summer (summer mean of $6.6 \mathrm{~cm}$ at the natural site and $5.8 \mathrm{~cm}$ at the artificial site) and shallowest in winter (winter mean of $2.9 \mathrm{~cm}$ at the natural site and $1.9 \mathrm{~cm}$ at the artificial site). However, the automated record shows that pool-level fluctuations did not simply reflect local water-table dynamics (e.g. Figure 5). Peat water tables tended to decline more rapidly than pool levels during dry periods and there was a greater variability in water-table depth than pool level change. The pool level records show a much smoother, damped signal to rainfall or recession periods than the peat water-table records. In response to storm events water-table changes in the peat around artificial and natural pools were not significantly different. However, water-table changes in the peat were significantly different from water-level changes in both the natural and artificial pools; pool hydrological responses were significantly different between pool types (oneway ANOVA, p<0.01, confirmed with a post-hoc Tukey test). After peak levels had been achieved during storms, water heights fell significantly faster in the peat around the pools than water levels within the pools (one-way ANOVA, $p<0.01$ ). Recession rates were significantly higher for dipwells 
at the artificial sites than the water levels both in the natural and artificial pools (one-way ANOVA, $p<0.01$ ) in the 6 and 12 hour period after peak water levels, but there were no significant differences in the 6 and 12 hour recession responses in the peat water tables between the natural and artificial sites. There was a significant difference between the mean response time to reach peak level between the pools and the dipwells (one-way ANOVA, $p<0.01$ ), and the water level responded fastest at the natural site in the peat around the pools, and slowest in the natural pools themselves.

Given that dipwells were typically around 1 to $4 \mathrm{~m}$ away from pools, our results for relative height differences between peat water tables and pool levels (Figures 4 and 5, Table 5) suggest that there are strong hydraulic gradients on site. Deep flows between pools and the peat and vice versa must be very slow as peat water tables and pool levels are rather different, with absolute peat water-table levels often being 20 to $30 \mathrm{~cm}$ higher or lower than water levels in pools only a metre away. This is corroborated by our hydraulic conductivity data for the site. Median hydraulic conductivity at 30 $\mathrm{cm}$ and $50 \mathrm{~cm}$ depths was $1.5 \times 10^{-5} \mathrm{~cm} \mathrm{~s}^{-1}$ (interquartile range $2.2 \times 10^{-5} \mathrm{~cm} \mathrm{~s}^{-1}$ ) and $1.4 \times 10^{-6} \mathrm{~cm}^{-1}$ $\mathrm{s}^{-1}$ (interquartile range $6.6 \times 10^{-6} \mathrm{~cm} \mathrm{~s}^{-1}$ ) respectively. Von Post scores ranged from 2 to 9 at $30 \mathrm{~cm}$ depth $($ median $=7, n=20)$ and 5 to 10 at $50 \mathrm{~cm}$ depth $($ median $=8, n=20)$.

\section{Discussion}

387 The DBPS values were significantly deeper and much more variable over time for the artificial 388 pools than the natural pools. Thus, biogeochemical and carbon cycling processes within natural 389 pools are unlikely to be replicated in artificial pools as their hydrological function is quite different. 390 Artificial pool levels fell at a significantly faster rate immediately following rainfall events than 391 water levels in natural pools. This enhanced fluctuation of pool levels in the artificial pools 392 compared to natural pools may result in more frequent aeration of pool walls followed by flushing 393 of the resultant dissolved organic carbon that may have been produced (Hamilton et al., 1994). 394 Water-table variability was also greater in the peat at the artificial pool site than in the nearby 
natural pool site, although both locations had relatively shallow mean water tables (within $5 \mathrm{~cm}$ of the peat surface).

There are several reasons why pool level variability and water-table variability were so much greater at the artificial pool site. It may be that during high flow the artificial pools still retain some connectivity to the old ditch system with pools overflowing along the course of the old ditches enabling pool levels to fall more quickly after peak than in the natural pool system. The rapid rise and fall of pool levels at the artificial pool site was not simply a function of small catchment areas for each pool. Pools 10 and 12 were both among the top six largest combined catchment areas of all pools studied (i.e. pool area plus contributing area; Table 1) and yet had more rapid water level recessions (6 hr and $12 \mathrm{hr}$ ) after storms than any of the six natural pools. However, the mean slope was slightly greater at the artificial pool site $\left(0.05 \mathrm{~m} \mathrm{~m}^{-1}\right.$ compared with $\left.0.04 \mathrm{~m} \mathrm{~m}^{-1}\right)$ and the ratio of catchment area to pool area was typically greater for the artificial pools (Table 1). Thus we might expect a more rapid increase in pool level in response to rainfall for the artificial pools. It may also be that some peat properties affected by ditch drainage had not recovered in the 11 to 13 years since restoration and there may be enhanced macropore and pipe drainage in the peat around the artificial 411 pools (Holden, 2005; Holden et al., 2006). Holden et al. (2011) found for a blanket peatland in northern England that 6 to 7 years after ditch blocking at a site where drains predominantly ran across slope (roughly parallel to the contour), the peat water tables were still significantly deeper and much more variable than those in nearby undrained peat, but slightly less variable than those in nearby drained peat without drain blocking. Evidence from other sites suggests that where blanket peatland drains run largely downslope, similar to those at our site, ditch blocking may only have a very small impact on local water tables and peatland function, at least in the short term (Green et al., 2017; Holden et al., 2017). Another important factor which could affect water-table and poollevel fluctuations is the bulk specific yield of the peatland. At the natural pool site there was a far 
421 pool depth was $\sim 40 \mathrm{~cm}$ and so considering only the upper $40 \mathrm{~cm}$ of the peatland, a specific yield of 422 pools $=1$, and mean specific yield for the upper $40 \mathrm{~cm}$ of peat $=0.22$, the bulk specific yield of the 423 natural pool site was 0.28 while it was 0.22 for the artificial pool site. Therefore, given the same 424 water input, the water level fluctuations would be expected to be greater at the artificial pool site 425 than at the natural pool site. However, we also showed that pool levels and water-tables in the 426 nearby peat were somewhat disconnected, with steep hydraulic gradients forming between the peat 427 and nearby pools due to very low peat hydraulic conductivity. Therefore, the bulk specific yield 428 concept may be of limited use in understanding the overall hydrological dynamics of blanket peat systems with pools. Nevertheless, the fact that pool DBPS values were on average $15 \mathrm{~cm}$, still 430 allows us to conclude that creating larger pool area in peatland restoration schemes may be 431 beneficial in reducing downstream flood risk for some storms. These benefits may not be fully 432 realised on occasions when the pools are already 'full' which is more likely in winter months when 433 evaporation rates are small.

Evaporation between rainfall events played a strong role in controlling pool level drawdown in the summer months meaning that variability in water levels was greatest at this time of year. The pool water levels were most drawn down during summer 2013, the first summer of monitoring. The subsequent winter was very wet but DBPS values in both the natural and artificial pool systems were generally greater in winter 2013 compared to the other two winters studied. It is not clear what caused this effect but such inter-annual variability in pool water levels, even in winter months may

441 have implications for carbon cycling and release and the hydrological function of the peatland. It 442 may be that the near-surface peat and pool sides became desiccated and cracked during the 443 unusually warm, dry summer of 2013 and this meant that in the subsequent winter (which was very 444 wet) more water could percolate out of the pool sides near the top of the peat. Desiccation cracking 445 is common in peatlands on bare peat faces during dry weather (Evans and Warburton, 2007) and 
macropore flow can be a very important pathway for water in near-surface blanket peat (Holden, 2009). It may have taken more than one winter for cracks to close up or seal with biofilms.

We surveyed for natural peat pipes around our 12 study pools using an underwater camera and we were unable to detect them. Therefore unlike the Labradorean small fen and raised bog study of

Price and Maloney (1994), pipes did not play a large role in pool functioning in our 12 study pools. However, we did observe piping at some of the other pools at the study site, where pipes provided one of several drainage routes for some pools and a water supply for other pools. We also found some cases where pipes connected pools to one another. Further work is required to establish whether the hydrological function of pipe-connected pools is different from those disconnected from peatland pipe networks.

The smaller artificial pools spilled out, on average, water equivalent to 54 times the mean volume of the pool per year. This relative value was six times lower for the natural pools although the actual volume of water that flowed out of the six natural pools was around ten times greater than that from the artificial pools. These rates of pool 'turnover' may be important for peatland chemistry and peat accumulation rates (Beer and Blodau, 2007; Morris and Waddington, 2011) and for understanding aquatic carbon fluxes from peatlands with pools, particularly if the carbon processing is different between natural and artificial pool systems. Pools with longer water residence times may be subject to enhanced photochemical processing of dissolved organic carbon (e.g. Pickard et al., 2017) (all pools were $\leq 50 \mathrm{~cm}$ deep); hence the quality of dissolved organic carbon may vary between pools which could be important for downstream water treatment for potable supply (Worrall and Burt, 468 2009; Moody and Worrall, 2017). On the other hand, the slower turnover of water in some larger 469 pools may mean that the remaining carbon is largely recalcitrant and little further processing can 470 occur, whereas in smaller pools processing of carbon can continue for longer periods if the pool 471 water volume is replaced more frequently. McEnroe et al. (2009) showed that smaller pools had 
consistently larger carbon dioxide and methane fluxes than larger pools in a raised bog in Canada. It should also be noted that we found that the rates of pool water replacement were highly variable and the volumes of water produced were not related simply to pool size as the upslope catchment area of each pool was also critical. Some very large natural pools had a relatively small upslope catchment area. Thus when sampling blanket peatland pools for their aquatic chemistry (Turner $e t$ $a l ., 2016)$ and also when considering potential impacts of pool processes on downstream river water chemistry, including aquatic carbon fluxes, and their role on carbon gas release to the atmosphere, it will be important in the future to consider pool topographic context and upslope contributing area in addition to pool dimensions. Pools of an equivalent size cannot be assumed to play an equivalent role in influencing aquatic fluxes from the peatland; pool size and their contributing area are both important.

Water levels and their fluctuations in pools were not the same as water-table depths and fluctuations in the nearby peat. Pool water level changes were much more subdued and less variable than watertable changes in the nearby peat. It would be expected that peat water tables would be more variable during storm events than pool water levels. Even as little as $2 \mathrm{~mm}$ of rainfall can often raise peat water tables by 2 to $4 \mathrm{~cm}$ as much of the pore space, even in unsaturated peat, is typically occupied by water and there is little available space for fresh rainwater (Gilman, 1994; Evans et al., 1999; Bourgault et al., 2017; University of Leeds Peat Club, 2017). However, the long-term difference between pool levels and peat water-table heights at the study site was also striking. This is an important finding as it shows that the hydrological function of pools, even small artificial ones, is quite different from the hydrological function of the peat mass. The absolute water-table height and nearby pool water levels were generally not the same and there were often steep hydraulic gradients on site. However, as the peat hydraulic conductivity at depths of $30 \mathrm{~cm}$ and $50 \mathrm{~cm}$ was very low, very little subsurface flow may be occurring and so connectivity between the pools and the peat system must be greatest at the peat surface or within a few $\mathrm{cm}$ of the peat surface. Thus storm 
498 events are important for connecting the peat system to pool systems, enabling pool water

499 replenishment and for flushing out of pools of potentially significant volumes of carbon and other 500 nutrients that may have been processed within the pool.

\section{Acknowledgements}

504 The research was funded by U.K. Natural Environment Research Council grant NE/J007609/1.

505 We would like to thank the Royal Society for the Protection of Birds, and particularly the team at 506 Forsinard Flows NNR, for granting permission to work at the site. Clare Gee was funded by a 507 Daphne Jackson Trust Fellowship, supported by the U.K. Natural Environment Research Council. 508 We gratefully acknowledge the review feedback from Mike Waddington and an anonymous 509 reviewer; their input helped to improve this manuscript. 
Armstrong A, Holden J, Kay P, McDonald AT, Gledhill S, Foulger M, Walker A. 2010. The impact of peatland drain-blocking on dissolved organic carbon loss and discolouration of water; results from a national survey. Journal of Hydrology, 381: 112-120.

Baird AJ, Holden J, Chapman PJ. 2009. Literature review of emissions of methane from peatlands. Project code: SP0574. Final report for Defra. 54pp.

Baird AJ, Surridge BWJ, Money RP. 2004. An assessment of piezometer method for measuring the hydraulic conductivity of a Cladium mariscus-Phragmites australis root mat in a Norfolk (UK) fen. Hydrological Processes, 18: 275-291.

Beadle J, Brown LE, Holden J. 2015. Biodiversity and ecosystem functioning in natural peat pools and those created by rewetting schemes. Wiley Interdisciplinary Reviews: Water, 2: 65-84. DOI: $10.1002 /$ wat1002.1063.

Beer J, Blodau C. 2007. Transport and thermodynamics constrain belowground carbon turnover in a northern peatland. Geochimica et Cosmochimica Acta, 71: 2989-3002.

Belyea LR. 2007. Climatic and topographic limits to the abundance of bog pools. Hydrological Processes, 21: 675-687.

Belyea LR, Lancaster J. 2002. Inferring landscape dynamics of bog pools from scaling relationships and spatial patterns. Journal of Ecology, 90: 223-234.

Boatman DJ. 1983. The Silver Flowe National Nature Reserve, Galloway, Scotland. Journal of Biogeography, 10: 163-174.

Bourgault MA, Larocque M, Garneau M. 2017. Quantification of peatland water storage capacity using the water table fluctuation method. Hydrological Processes, 31: 1184-1195.

Brown LE, Ramchunder SJ, Beadle JM, Holden J. 2016. Macroinvertebrate community assembly in pools created during peatland restoration. Science of the Total Environment, 569-570: 361372.

Burt TP, Gardiner AT. 1984. Runoff and sediment production in a small peat-covered catchment: some preliminary results. In: Catchment experiments in fluvial geomorphology, Burt TP, Walling DE (eds.) Geobooks: Norwich; 133-152.

Downie IS, Coulson JC, Foster GN, Whitfield DP. 1998. Distribution of aquatic macroinvertebrates within peatland pool complexes in the Flow Country, Scotland. Hydrobiologia, 377: 95, DOI: 10.1023/A:1003267022820.

Evans M, Warburton J. 2007. The Geomorphology of Upland Peat: Pattern, Process, Form. WileyBlackwell; pp.

Evans MG, Burt TP, Holden J, Adamson JK. 1999. Runoff generation and water table fluctuations in blanket peat: evidence from UK data spanning the dry summer of 1995. Journal of Hydrology, 221: 141-160.

Foster DR, Glaser PH. 1985. The raised bogs of southeastern Labrador, Canada: classification, distribution, vegetation and recent dynamics. Journal of Ecology, 74: 44-71.

Gallego-Sala AV, Prentice IC. 2012. Blanket peat biome endangered by climate change. Nature Climate Change, 3: 152-155, doi: 110.1038/NCLIMATE1672.

Gilman K. 1994. Hydrology and wetland conservation. John Wiley: Chichester; pp 101.

Glaser PH. 1998. The distribution and origin of mire pools. In: Patterned Mires and Mire Pools : origin and Development; flora and fauna, Standen V, Tallis JH, Meade R (eds.) University of Durham, Durham; 4-25.

Green SM, Baird AJ, Holden J, Reed D, Birch K, Jones P. 2017. An experimental study on the response of blanket bog vegetation and water tables to ditch blocking. Wetlands Ecology and Management, doi:10.1007/s11273-017-9545-z.

Hamilton JD, Kelly CA, Rudd JWM, Hesslein RH, Roulet NT. 1994. Flux to the atmosphere of $\mathrm{CH} 4$ and $\mathrm{CO} 2$ from wetland ponds on the Hudson Bay lowlands (HBLs). Journal of Geophysical Research : Atmospheres, 99: 1495-1510. 
Hobbs NB. 1986. Mire Morphology and the Properties and Behavior of Some British and Foreign Peats. Quarterly Journal of Engineering Geology, 19: 7-80.

Holden J. 2005. Controls of soil pipe frequency in upland blanket peat. Journal of Geophysical Research, 110: F01002, doi:01010.01029/02004JF000143.

Holden J. 2009. Flow through macropores of different size classes in blanket peat. Journal of Hydrology, 364: 342-348.

Holden J, Evans MG, Burt TP, Horton M. 2006. Impact of land drainage on peatland hydrology. Journal of Environmental Quality, 35: 1764-1778, doi:1710.2134/jeq2005.0477.

Holden J, Gascoign M, Bosanko NR. 2007. Erosion and natural revegetation associated with surface land drains in upland peatlands. Earth Surface Processes and Landforms, 32: 15471557.

Holden J, Green SM, Baird AJ, Grayson RP, Dooling GP, Chapman PJ, Evans CD, Peacock M, Swindles G. 2017. The impact of ditch blocking on the hydrological functioning of blanket peatlands. Hydrological Processes, 31: 525-539, doi: 510.1002/hyp.11031.

Holden J, Wallage ZE, Lane SN, McDonald AT. 2011. Water table dynamics in drained and restored blanket peat. Journal of Hydrology, 402: 103-114.

Höper H, Augustin J, Cagampan JP, Drösler M, Lundin L, Moors E, Vasander H, J.M. W, Wilson D. 2008. Restoration of peatlands and greenhouse gas balances. In: Peatlands and Climate Change, Strack M (ed.) International Peat Society and Saarijärven Offset Oy: Saarijärvi, Finland; 182-210.

Hvorslev MJ. 1951. Time lag and soil permeability in groundwater observations., Corps of Engineers, United States Army: Vicksburg, Mississippi; pp.

Ingram HAP. 1983. Hydrology. In: Ecosystems of the world 4A, mires: swamp, bog, fen and moor, Gore AJP (ed.) Elsevier: Oxford; 67-158.

Ingram HAP. 1987. Ecohydrology of Scottish peatlands. Transactions of the Royal Society of Edinburgh: Earth Sciences, 78: 278-296.

Linacre ET. 1993. Data-sparse estimation of lake evaporation, using a simplified Penman equation. Agricultural and Forest Meteorology, 64: 237-256.

Lindsay RA, Charman DJ, Everingham F, O'Reilly RM, Palmer MA, Rowell TA, Stroud DA. 1988. The Flow Country - the peatlands of Caithness and Sutherland. JNCC: Edinburgh; pp.

Mayfield B, Pearson MC. 1972. Human interference with the north Derbyshire blanket peat. East Midland Geographer, 12: 245-251.

McEnroe NA, Roulet NT, Moore TR, Garneau M. 2009. Do pool surface area and depth control $\mathrm{Co} 2$ and $\mathrm{CH} 4$ fluxes from an ombrotrophic raised bog, James Bay, Canada? Journal of Geophysical Research, 114: G01001, doi: 01010.01029/02007JG000639.

McMahon TA, Finlayson BL, Peel MC. 2016. Historical developments of models for estimating evaporation using standard meteorological data. Wiley Interdisciplinary Reviews: Water, 3: 788-818, doi: 710.1002/wat1002.1172.

Mitchell G. 1990. Natural discolouration in freshwater: Chemical composition and environmental genesis. Progress in Physical Geography, 14: 317-334.

Mitchell G, McDonald AT. 1995. Catchment Characterization as a Tool for Upland Water-Quality Management. Journal of Environmental Management, 44: 83-95.

Moody CS, Worrall F. 2017. Modelling rates of DOC degradation using DOM composition and hydroclimatic variables. Journal of Geophysical Research: Biogeosciences, 122: 1175-1191. doi: 1110.1002/2016JG003493.

Morris PJ, Waddington JM. 2011. Groundwater residence-time distributions in peatlands: implications for peat decomposition and accumulation. Water Resources Research, 47: W0251. DOI: 10.1029.2010WR009492.

Parry LE, Holden J, Chapman PJ. 2014. Restoration of blanket peatlands. Journal of Environmental Management, 133: 193-205. 
Pelletier L, Strachan IB, Garneau M, Roulet NT. 2014. Carbon release from boreal peatland open water pools: Implication for the contemporary C exchange. Journal of Geophysical Research Biogeosciences, 119: 207-222, doi:210.1002/2013JG002423.

Penman HL. 1948. Natural evaporation from open water, bare soil and grass. Proceedings of the Royal Society A, 193: 120-145.

Pickard A. 2016. Assessing the photoreactivity of peatland derived carbon in aquatic systems. University of Edinburgh.

Pickard A, Heal K, McLeod A, Dinsmore KJ. 2017. Temporal changes in photoreactivity of dissolved organic carbon and implications for aquatic carbon fluxes from peatlands. Biogeosciences, 14: 1793-1809, doi: 1710.5194/bg-1714-1793-2017.

Price JS, Maloney DA. 1994. Hydrology of a patterned bog-fen complex in southeastern Labrador, Canada. Nordic Hydrology, 25: 313-330.

Price JS, Rochefort L, Campeau S. 2002. On the use of shallow basins to restore cutover peatlands: Hydrology. Restoration Ecology, 10: 259-266.

Quinton WL, Roulet NT. 1998. Spring and summer runoff hydrology of a subarctic patterned wetland. Arctic and Alpine Research, 30: 285-294.

Ratcliffe DA, Oswald PH. 1988. The flow country; the peatlands of Caithness and Sutherland. Nature Conservancy Council: Peterborough; pp.

Ratcliffe J, Payne RJ. 2016. Palaeoecological studies as a source of peat depth data: A discussion and data compilation for Scotland. Mires and Peat, 18: Article 13, doi: 10.19189/MaP.12016.OMB.19234.

Roulet NT, Jano A, Kelly CA, Klinger LF, Moore TR, Protz R, Ritter JA, Rouse WR. 1994. Role of the Hudson-Bay lowland as a source of atmospheric methane. Journal of Geophysical Research : Atmospheres: 1439-1454.

Rydin H, Jeglum J. 2006. The Biology of Peatlands. Oxford University Press: Oxford; pp.

Sjors H. 1983. Mires of Sweden. In: Mires: Swamp, Bog, Fen and Moor, Gore AJP (ed.) Elsevier: Amsterdam; 69-94.

Stewart AJA, Lance AN. 1983. Moor-draining - a review of impacts on land use. Journal of Environmental Management, 17: 81-99.

Turner TE, Billett MF, Baird AJ, Chapman PJ, Dinsmore KJ, Holden J. 2016. Regional variation in the biogeochemical and physical characteristics of natural peatland pools. Science of the Total Environment, 545-546.

University of Leeds Peat Club, Bacon KL, Baird AJ, Blundell A, Bourgault M-A, Chapman PJ, Dargie G, Dooling GP, Gee C, Holden J, Kelly T, McKendrick-Smith KA, Morris PJ, Noble A, Palmer SM, Quillet A, Swindles GT, Watson EJ, Young DM. 2017. Questioning ten common assumptions about peatlands. Mires and Peat, 19: 1-23, doi:20.19189/MaP.12016.OMB.19253.

Waddington JM, Roulet NT. 1996. Atmosphere-wetland carbon exchanges: Scale dependency of $\mathrm{CO} 2$ and $\mathrm{CH} 4$ exchange on the developmental topography of a peatland. Global Biogeochemical Cycles, 10: 233-245.

Worrall F, Burt TP. 2009. Changes in DOC treatability: Indications of compositional changes in DOC trends. Journal of Hydrology, 366: 1-8.

Xu J, Morris PJ, Liu J, Holden J. 2018. PEATMAP: Refining estimates of global peatland distribution based on a meta-analysis. Catena, 160: 134-140.

Yu Z, Loisel J, Brosseau DP, Beilman DW, Hunt SJ. 2010. Global peatland dynamics since the Last Glacial Maximum. Geophysical Research Letters, 37, L13402: doi:10.1029/2010GL043584.

Yu ZC. 2012. Northern peatland carbon stocks and dynamics: a review. Biogeosciences, 9: 40714085. 
662

663

664

665

666

667

668 


\begin{tabular}{|l|c|c|c|c|c|c|}
\hline Pool & $\begin{array}{c}\text { Pool surface } \\
\text { area } \\
\left(\mathrm{m}^{2}\right)\end{array}$ & $\begin{array}{c}\text { Length of } \\
\text { pool } \\
\text { perimeter } \\
(\mathrm{m})\end{array}$ & $\begin{array}{c}\text { Length of } \\
\text { pool } \\
\text { perimeter } \\
\text { receiving } \\
\text { surface } \\
\text { water from } \\
\text { topographic } \\
\text { area above } \\
\text { pool (m) }\end{array}$ & $\begin{array}{c}\text { Mean pool } \\
\text { water } \\
\text { height } \\
\text { above bed } \\
(\mathrm{m})\end{array}$ & $\begin{array}{c}\text { Upslope } \\
\text { surface } \\
\text { catchment } \\
\text { area }\left(\mathrm{m}^{2}\right)\end{array}$ & $\begin{array}{c}\text { Catchment } \\
\text { area / Pool } \\
\text { area }\end{array}$ \\
\hline Natural & & & 231 & 0.50 & 427 & \\
\hline Pool 1 & 868 & 246 & 21 & 0.42 & 1325 & 34.0 \\
\hline Pool 2 & 39 & 25 & 8 & 0.30 & 1387 & 154.1 \\
\hline Pool 3 & 9 & 19 & 44 & 0.43 & 177 & 1.5 \\
\hline Pool 4 & 115 & 58 & 11 & 0.31 & 31 & 2.1 \\
\hline Pool 5 & 15 & 21 & 10 & 0.30 & 89 & 3.7 \\
\hline Pool 6 & 24 & 19 & & & & \\
\hline Artificial & & & 3.0 & 0.34 & 45 & 7.5 \\
\hline Pool 7 & 6 & 12 & 2.5 & 0.37 & 77 & 38.5 \\
\hline Pool 8 & 2 & 8 & 2.5 & 0.38 & 57 & 9.5 \\
\hline Pool 9 & 6 & 13 & 1.5 & 0.39 & 1264 & 316.0 \\
\hline Pool 10 & 4 & 8 & 2.0 & 0.43 & 21 & 21.0 \\
\hline Pool 11 & 1 & 7 & 0.5 & 0.47 & 203 & 101.5 \\
\hline Pool 12 & 2 & 2 & & & & \\
\hline
\end{tabular}


676 Table 2. Mean DBPS, $\mathrm{cm}$ (top row in each cell) and interquartile range, $\mathrm{cm}$ (bottom row in each cell). Summer $=$ JJA, Autumn $=\mathrm{SON}$, Winter $=\mathrm{DJF}$,

677 Spring = MAM. $* 2015 / 16$ does not include data from 29 January onwards.

\begin{tabular}{|c|c|c|c|c|c|c|c|c|c|c|c|}
\hline Season & $\begin{array}{r}\text { Summer } \\
2013 \\
\end{array}$ & $\begin{array}{r}\text { Autumn } \\
2013 \\
\end{array}$ & $\begin{array}{r}\text { Winter } \\
2013 / 14 \\
\end{array}$ & $\begin{array}{r}\text { Spring } \\
2014 \\
\end{array}$ & $\begin{array}{r}\text { Summer } \\
2014 \\
\end{array}$ & $\begin{array}{r}\text { Autumn } \\
2014 \\
\end{array}$ & $\begin{array}{r}\text { Winter } \\
2014 / 15 \\
\end{array}$ & $\begin{array}{r}\text { Spring } \\
2015 \\
\end{array}$ & $\begin{array}{r}\text { Summer } \\
2015 \\
\end{array}$ & $\begin{array}{r}\text { Autumn } \\
2015 \\
\end{array}$ & $\begin{array}{r}\text { Winter } \\
2015 / 16^{*} \\
\end{array}$ \\
\hline Precipitation, $\mathrm{cm}$ & 110.8 & 251.4 & 460.6 & 268.3 & 250.0 & 209.8 & 298.4 & 174.6 & 143.0 & 153.0 & 180.4 \\
\hline Pool evaporation, $\mathrm{cm}$ & 248.2 & 57.8 & 2.0 & 75.1 & 293.8 & 61.6 & 1.7 & 57.6 & 195.8 & 54.2 & 0.9 \\
\hline \multirow[t]{2}{*}{ Pool 1} & 27.3 & 23.2 & 17.5 & 18.2 & 19.6 & 16.7 & 14.9 & 15.4 & 16.0 & 14.6 & 11.9 \\
\hline & 6.7 & 8.0 & 0.5 & 1.2 & 4.3 & 2.5 & 0.9 & 1.0 & 1.6 & 1.9 & 0.6 \\
\hline \multirow[t]{2}{*}{ Pool 2} & 29.2 & 24.3 & 18.0 & 19.0 & 21.7 & 18.3 & 16.8 & 17.7 & 19.5 & 18.4 & 15.9 \\
\hline & 8.2 & 10.8 & 0.4 & 1.6 & 5.5 & 2.0 & 0.4 & 1.4 & 3.0 & 2.7 & 0.4 \\
\hline \multirow[t]{2}{*}{ Pool 3} & 28.2 & 22.3 & 18.5 & 19.3 & 21.0 & 18.1 & 16.5 & 17.3 & 18.2 & 17.1 & 15.2 \\
\hline & 6.5 & 4.1 & 0.6 & 1.4 & 4.2 & 2.3 & 0.6 & 1.6 & 2.3 & 2.5 & 0.4 \\
\hline \multirow[t]{2}{*}{ Pool 4} & 26.2 & 20.9 & 15.4 & 16.2 & 18.8 & 15.5 & 13.4 & 14.3 & 15.3 & 14.2 & 11.8 \\
\hline & 7.1 & 7.2 & 0.5 & 1.5 & 5.4 & 3.3 & 0.7 & 2.0 & 2.4 & 2.4 & 0.6 \\
\hline \multirow[t]{2}{*}{ Pool 5} & 19.2 & 12.6 & 9.8 & 10.3 & 12.1 & 9.4 & 7.5 & 7.9 & 8.7 & 7.7 & 5.9 \\
\hline & 5.6 & 3.6 & 0.6 & 1.6 & 4.9 & 2.8 & 0.9 & 1.6 & 2.3 & 2.2 & 0.3 \\
\hline \multirow[t]{2}{*}{ Pool 6} & 24.9 & 18.4 & 15.2 & 16.1 & 18.0 & 15.1 & 13.4 & 14.3 & 15.3 & 14.3 & 13.0 \\
\hline & 6.7 & 4.1 & 0.5 & 1.7 & 5.2 & 2.8 & 0.6 & 1.3 & 2.1 & 1.5 & 0.3 \\
\hline \multirow[t]{2}{*}{ All natural pools } & 25.8 & 20.3 & 15.7 & 16.5 & 18.5 & 15.5 & 13.7 & 14.5 & 15.5 & 14.4 & 12.3 \\
\hline & 6.8 & 6.4 & 0.5 & 1.5 & 4.9 & 2.6 & 0.6 & 1.4 & 2.3 & 2.2 & 0.4 \\
\hline \multirow[t]{2}{*}{ Pool 7} & 19.8 & 13.0 & 11.0 & 11.3 & 12.3 & 10.2 & 9.1 & 10.2 & 10.7 & 10.2 & 8.4 \\
\hline & 9.3 & 1.8 & 0.6 & 1.8 & 3.9 & 2.1 & 1.2 & 2.3 & 2.2 & 1.8 & 0.7 \\
\hline \multirow[t]{2}{*}{ Pool 8} & 18.1 & 9.5 & 7.6 & 9.0 & 9.9 & 7.7 & 5.9 & 7.4 & 8.8 & 7.2 & 5.3 \\
\hline & 10.2 & 2.2 & 1.0 & 2.3 & 3.9 & 3.2 & 1.4 & 2.6 & 2.9 & 2.4 & 1.4 \\
\hline \multirow[t]{2}{*}{ Pool 9} & 23.6 & 16.7 & 14.3 & 15.2 & 16.1 & 14.4 & 12.8 & 13.8 & 14.8 & 14.1 & 12.0 \\
\hline & 8.3 & 2.7 & 0.9 & 2.3 & 3.6 & 2.8 & 1.1 & 1.9 & 2.1 & 2.9 & 1.0 \\
\hline \multirow[t]{2}{*}{ Pool 10} & 21.9 & 12.4 & 9.4 & 10.6 & 12.6 & 10.1 & 8.1 & 9.4 & 10.5 & 9.6 & 7.2 \\
\hline & 9.5 & 3.1 & 1.2 & 2.1 & 6.4 & 3.1 & 1.4 & 2.0 & 3.3 & 3.1 & 1.3 \\
\hline \multirow[t]{2}{*}{ Pool 11} & 29.2 & 20.0 & 17.0 & 18.3 & 20.2 & 17.5 & 15.0 & 16.8 & 19.0 & 17.8 & 14.7 \\
\hline & 7.7 & 3.3 & 1.5 & 2.6 & 6.3 & 3.6 & 2.1 & 2.7 & 3.9 & 4.0 & 1.9 \\
\hline \multirow[t]{2}{*}{ Pool 12} & 25.9 & 16.0 & 12.7 & 14.4 & 16.4 & 13.0 & 10.3 & 11.7 & 13.7 & 12.7 & 9.2 \\
\hline & 9.6 & 3.6 & 2.0 & 4.1 & 8.0 & 4.9 & 0.9 & 3.1 & 6.1 & 5.0 & 0.8 \\
\hline \multirow[t]{2}{*}{ All artificial pools } & 23.1 & 14.6 & 12.0 & 13.2 & 14.6 & 12.2 & 10.2 & 11.5 & 12.9 & 11.9 & 9.5 \\
\hline & 9.1 & 2.7 & 1.1 & 2.5 & 5.4 & 3.3 & 1.4 & 2.2 & 3.3 & 3.1 & 1.1 \\
\hline
\end{tabular}




\begin{tabular}{|l|c|c|}
\hline & Pool outflow, $\mathrm{m}^{3} \mathrm{yr}^{-1}$ & $\begin{array}{l}\text { Number of times the } \\
\text { equivalent pool volume was } \\
\text { recharged, } \mathrm{yr}^{-1}\end{array}$ \\
\hline Pool 1 & 818.4 & 1.9 \\
\hline Pool 2 & 1047.8 & 64.4 \\
\hline Pool 3 & 1079.0 & 402.3 \\
\hline Pool 4 & 201.7 & 4.1 \\
\hline Pool 5 & 32.4 & 7.1 \\
\hline Pool 6 & 82.4 & 11.4 \\
\hline Natural median & 510.0 & 9.2 \\
\hline Pool 7 & 37.7 & 19.2 \\
\hline Pool 8 & 59.2 & 69.7 \\
\hline Pool 9 & 47.2 & 22.2 \\
\hline Pool 10 & 980.4 & 714.3 \\
\hline Pool 11 & 17.1 & 38.5 \\
\hline Pool 12 & 158.4 & 194.2 \\
\hline Artificial median & 53.2 & 54.1 \\
\hline
\end{tabular}

687 
Table 4. Mean pool water level responses to 20 storm events

689

\begin{tabular}{|l|c|c|c|c|c|}
\hline & $\begin{array}{c}\text { Pool level } \\
\text { change } \\
(\mathrm{cm})\end{array}$ & $\begin{array}{c}\text { Smallest DBPS } \\
\text { in storm } \\
(\mathrm{cm})\end{array}$ & $\begin{array}{c}\text { Time from rain } \\
\text { start to smallest } \\
\text { DBPS } \\
(\mathrm{h})\end{array}$ & $\begin{array}{c}\text { Increase in } \\
\text { DBPS6 hrs after } \\
\text { smallest depth } \\
\left(\mathrm{cm} \mathrm{h}^{-1}\right)\end{array}$ & $\begin{array}{c}\text { Increase in } \\
\text { DBPS12 hrs } \\
\text { after smallest } \\
\text { depth }\left(\mathrm{cm} \mathrm{h}^{-1}\right)\end{array}$ \\
\hline Pool 1 & 2.2 & 15.5 & 19.5 & 0.10 & 0.08 \\
\hline Pool 2 & 1.7 & 17.7 & 18.4 & 0.05 & 0.04 \\
\hline Pool 3 & 2.0 & 17.1 & 17.6 & 0.08 & 0.06 \\
\hline Pool 4 & 1.9 & 14.5 & 19.3 & 0.07 & 0.04 \\
\hline Pool 5 & 1.9 & 8.1 & 14.2 & 0.09 & 0.06 \\
\hline Pool 6 & 2.0 & 14.1 & 16.5 & 0.09 & 0.05 \\
\hline Natural mean & 1.9 & 14.5 & 17.6 & 0.08 & 0.06 \\
\hline Pool 7 & 2.4 & 8.7 & 14.2 & 0.16 & 0.10 \\
\hline Pool 8 & 3.5 & 4.9 & 11.8 & 0.27 & 0.16 \\
\hline Pool 9 & 3.0 & 11.8 & 12.4 & 0.23 & 0.14 \\
\hline Pool 10 & 3.2 & 7.3 & 16.9 & 0.12 & 0.09 \\
\hline Pool 11 & 5.1 & 13.2 & 16.9 & 0.22 & 0.19 \\
\hline Pool 12 & 4.4 & 9.2 & 15.3 & 0.20 & 0.16 \\
\hline Artificial mean & 3.6 & 9.2 & 14.6 & 0.20 & 0.14 \\
\hline
\end{tabular}


Table 5. Water level in the pools and surrounding peat, $\mathrm{m}$, relative to a local datum for 21st May 2015 to 28th January 2016. Note that one datum point was used for the natural pool site and a different datum point was used for the artificial pool site.

695

\begin{tabular}{|l|r|r|r|r|r|r|}
\hline Pool/Dipwell & Mean & Std deviation & IQR & Minimum & Maximum & Range \\
\hline Pool 1 & 99.729 & 0.019 & 0.038 & 99.693 & 99.781 & 0.088 \\
\hline Pool 2 & 99.689 & 0.020 & 0.036 & 99.643 & 99.723 & 0.081 \\
\hline Pool 3 & 99.574 & 0.017 & 0.023 & 99.534 & 99.605 & 0.072 \\
\hline Pool 4 & 98.682 & 0.018 & 0.034 & 98.639 & 98.716 & 0.077 \\
\hline Pool 5 & 98.327 & 0.015 & 0.027 & 98.290 & 98.363 & 0.073 \\
\hline Pool 6 & 98.216 & 0.013 & 0.021 & 98.180 & 98.243 & 0.063 \\
\hline Dipwell P1U & 99.800 & 0.014 & 0.020 & 99.758 & 99.833 & 0.074 \\
\hline Dipwell P1M & 99.724 & 0.023 & 0.036 & 99.662 & 99.770 & 0.109 \\
\hline Dipwell P1D & 99.621 & 0.051 & 0.080 & 99.474 & 99.686 & 0.212 \\
\hline Dipwell P4U & 98.741 & 0.024 & 0.033 & 98.657 & 98.778 & 0.122 \\
\hline Dipwell P4M & 98.457 & 0.021 & 0.033 & 98.391 & 98.501 & 0.110 \\
\hline Dipwell P4D & 98.380 & 0.028 & 0.047 & 98.316 & 98.449 & 0.133 \\
\hline Pool 7 & 99.570 & 0.016 & 0.021 & 99.517 & 99.608 & 0.091 \\
\hline Pool 8 & 100.215 & 0.021 & 0.034 & 100.159 & 100.265 & 0.106 \\
\hline Pool 9 & 100.969 & 0.018 & 0.029 & 100.929 & 101.017 & 0.088 \\
\hline Pool 10 & 97.8618 & 0.022 & 0.032 & 97.796 & 97.927 & 0.130 \\
\hline Pool 11 & 101.400 & 0.029 & 0.042 & 101.320 & 101.484 & 0.154 \\
\hline Pool 12 & 99.886 & 0.033 & 0.049 & 99.809 & 99.964 & 0.155 \\
\hline Dipwell P8U & 100.449 & 0.045 & 0.041 & 100.300 & 100.522 & 0.222 \\
\hline Dipwell P8D & 100.104 & 0.027 & 0.026 & 99.992 & 100.142 & 0.150 \\
\hline Dipwell P11U & 101.641 & 0.032 & 0.040 & 101.556 & 101.759 & 0.203 \\
\hline Dipwell P11D & 101.311 & 0.025 & 0.036 & 101.230 & 101.372 & 0.142 \\
\hline
\end{tabular}

696 


\section{Figure captions}

Figure 1. Location of the 12 study pools. Natural pools are shown in red and artificial pools in green. Also shown are $2 \mathrm{~m}$ contours and the area of felled forest. The location within the UK is shown in the inset map. Imagery used with permission from Esri, image taken 2016.

Figure 2. Time-series of pool levels, DBPS, 15-minute interval data, and daily rainfall.

Figure 3. Manually measured water-table depths in the peat $1 \mathrm{~m}$ from natural pools (black) and artificial pools (grey). The box shows the interquartile range, error bars show range, crosses show 1st and 99th percentiles, solid square box shows mean and the horizontal dashed line shows the median.

Figure 4. Comparisons of relative pool water level and water-table height in the peat nearby for Pools 1, 4, 8 and 11, based on automated records. The box shows the interquartile range, error bars show range, crosses show 1st and 99th percentiles, solid square box shows mean and the grey line shows median. $\mathrm{U}=$ upslope of pool, $\mathrm{M}=$ adjacent to pool, $\mathrm{D}=$ downslope from pool.

Figure 5. Examples of pool level and water-table time-series from Pool 4 in the natural pool system (upper panel) and Pool 8 in the artificial pool system (lower panel). Water levels shown in each plot are all relative to the same local datum; one datum was used for the natural pool site while a different datum was used at the artificial pool site. 
721 Figure 1. Location of the 12 study pools, natural pools are shown in red and artificial pools in green. 722 Also shown are $2 \mathrm{~m}$ contours and the area of felled forest. The location within the UK is shown in 723 the inset map. Imagery used with permission from Esri, image taken 2016.

724

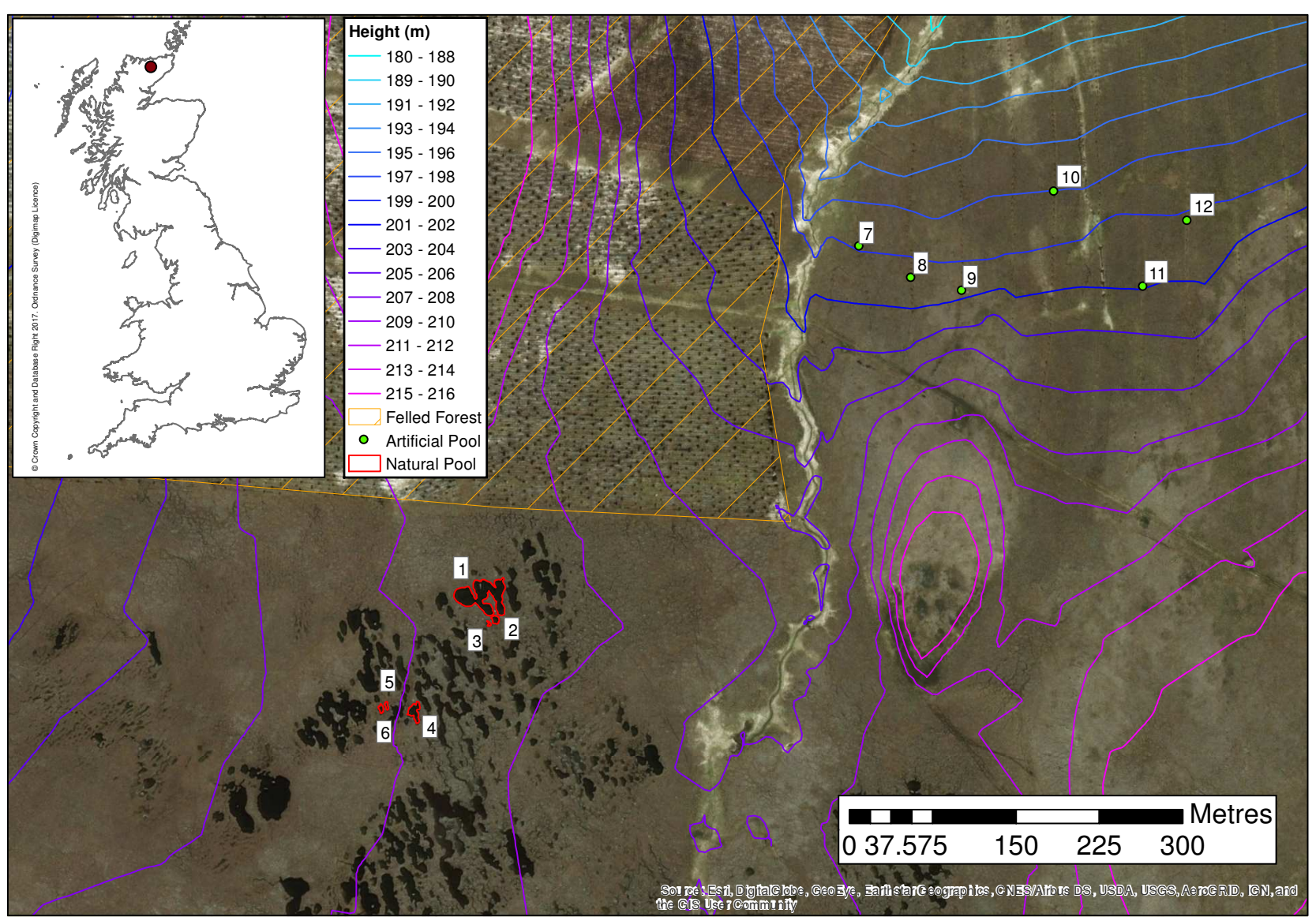


731

732
Figure 2. Time-series of pool levels, DBPS, 15-minute interval data, and daily rainfall.
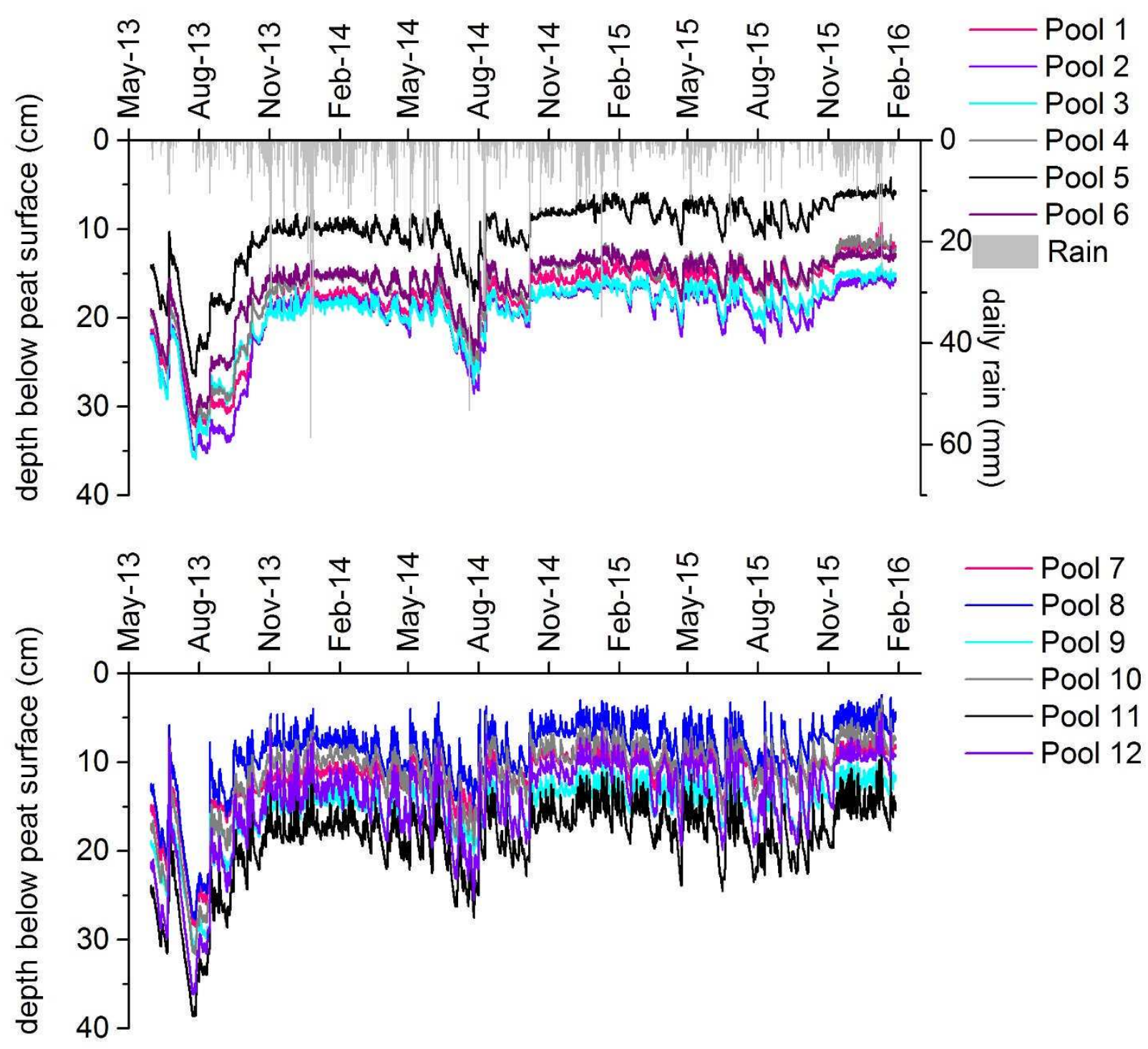
738 Figure 3. Manually measured water-table depths in the peat $1 \mathrm{~m}$ from natural pools (black) and 739 artificial pools (grey). The box shows the interquartile range, error bars show range, crosses show 740 1st and 99th percentiles, solid square box shows mean and the horizontal dashed line shows the 741 median.

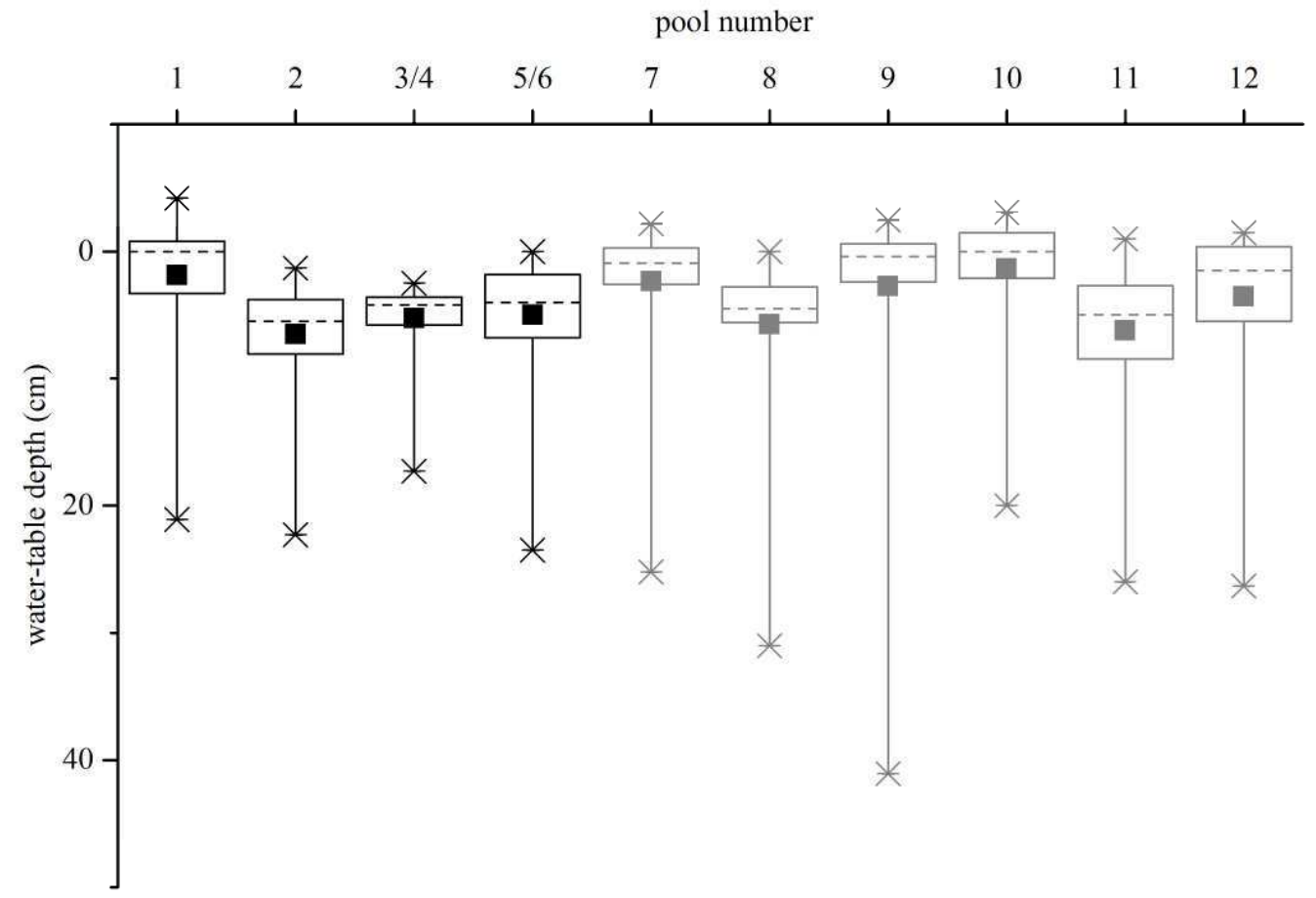

742 
Figure 4. Comparisons of relative pool water level and water-table height in the peat nearby for Pools $1,4,8$ and 11, based on automated records. The box shows the interquartile range, error bars show range, crosses show 1st and 99th percentiles, solid square box shows mean and the grey line shows median. $U=$ upslope of pool, $\mathrm{M}=$ adjacent to pool, $\mathrm{D}=$ downslope from pool.
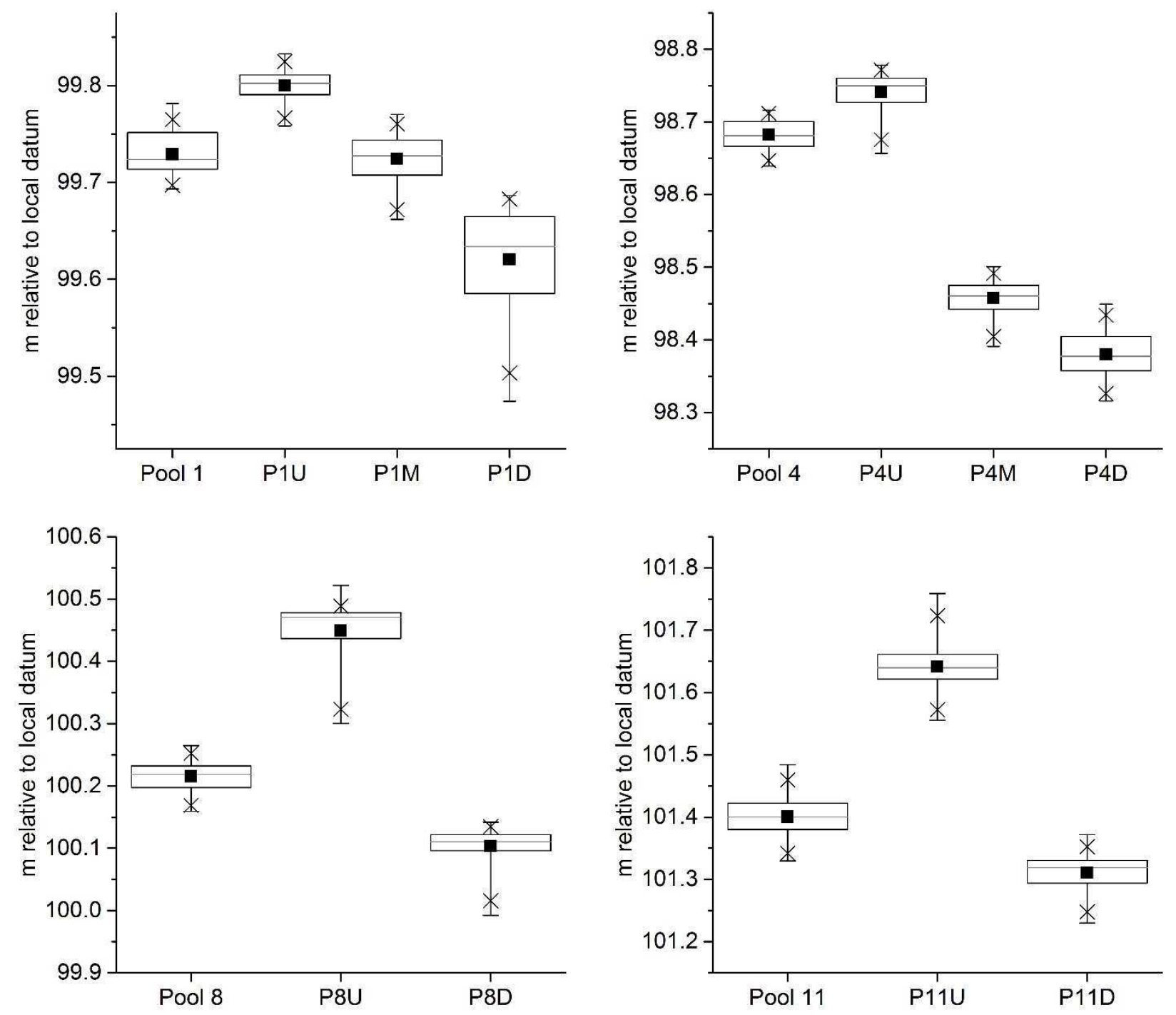
Figure 5. Examples of pool level and water-table time-series from Pool 4 in the natural pool system (upper panel) and Pool 8 in the artificial pool system (lower panel). Water levels shown in each plot are all relative to the same local datum; one datum was used for the natural pool site while a different datum was used at the 754 artificial pool site.
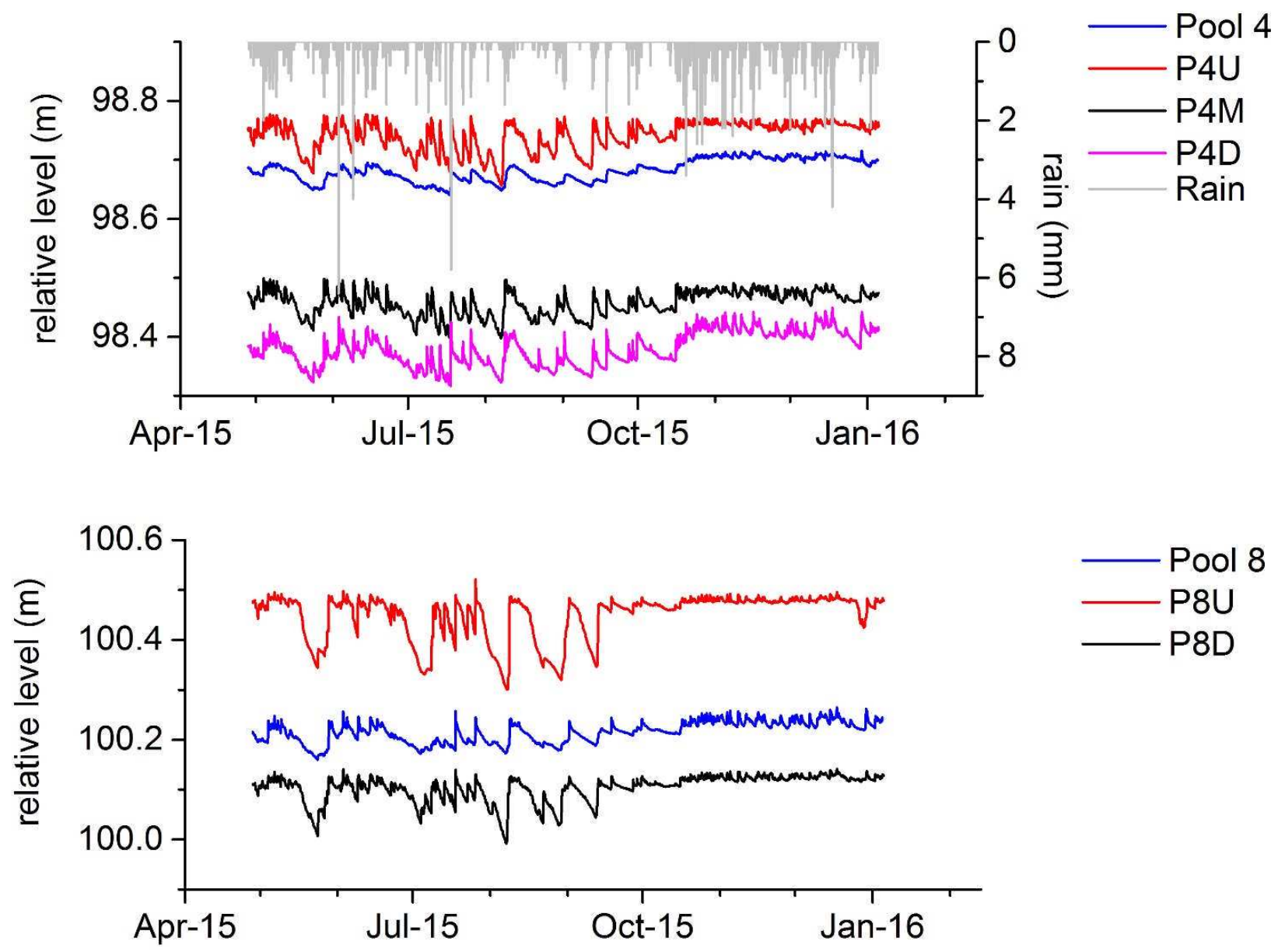